\title{
NASIONALISME DALAM CERPEN "MARDIJKER" KARYA DAMHURI MUHAMMAD: KAJIAN POSKOLONIALISME
}

\author{
Emma Rahmawati Fatimah \\ Ilmu Sastra, Fakultas Ilmu Budaya Universitas Gadjah Mada \\ Email: emma.rahma0924@gmail.com
}

\begin{abstract}
Abstrak
Tulisan ini berusaha melihat bagaimana nasionalisme yang terdapat dalam sebuah cerpen berjudul "Mardijker" karya Damhuri Muhammad dengan perspektif poskolonialisme. Cerpen ini berlatar belakang sejarah kolonial mengenai keberadaan kaum Belanda Depok yang merupakan keturunan budak yang dibebaskan oleh tuan tanah Belanda di daerah Depok, Cornelis Chastelein. Perspektif poskolonial yang digunakan untuk menganalisis cerpen ini berusaha mengidentifikasi apakah nasionalisme yang tercermin dalam perilaku tokoh-tokoh cerpen ini merupakan nasionalisme sentrifugal ataukah nasionalisme sentripetal. Analisis cerpen ini dilakukan dalam tataran kontekstual yang merupakan kehendak untuk membangun sebuah dunia yang di dalamnya Timur dapat mengaktualisasikan dirinya secara bebas, lepas dari tekanan dominasi Barat. Hasil yang didapatkan adalah nasionalisme yang ditemukan dalam cerpen "Mardijker" ini merupakan nasionalisme sentripetal yang menarik ke masa lalu dan menganggap dunia itu sudah ada sebelumnya dan dapat ditemukan kembali.
\end{abstract}

Kata kunci: nasionalisme, poskolonialisme, nasionalisme sentripetal.

\begin{abstract}
This writing tries to see nationalism reflected from a short story entitled "Mardijker" by Damburi Muhammad using postcolonial perspective. This short story also contain historical background about Belanda Depok, a group of slaves who work for Dutch landlord in Depok, Cornelis Chastelein, which later he released all the slaves. Postcolonial perspective is used to identify nationalism reflected from the character of the story, whether it is a centrifugal or a centripetal nationalism. The analysis is done in contextual level of nationalism, which is considered as a will to establish a world which in that world, East can actualize their self in a free way, without any pressure from West. The nationalism that present in the short story is a centripetal nationalism which pulled back the memories to the past and considered that the world had been exist before and can be found again.
\end{abstract}

Keywords: nationalism, postcolonialism, centripetal nationalism.

\section{Pendahuluan}

Sejak studi poskolonialisme diperkenalkan sebagai upaya menjawab kegelisahan intelektual dunia ketiga untuk melihat budaya nasional dan memisahkannya dengan apa yang menjadi warisan kolonialisme, pembicaraan seputar nasionalisme selalu hadir di dalamnya. Corak pendekatan poskolonial dalam upayanya melihat nasionalisme selalu cenderung mengembalikan Barat ke batas-batas alamiahnya atau sebaliknya, berusaha melihat Timur bukan sebagai turunan dari identitas Barat. Hal ini dikarenakan apa yang dimaksud dengan Barat sebagai kebudayaan tidak hanya ada dalam batas geografi yang selama ini kita pahami sebagai Eropa, melainkan juga telah terbawa memenuhi ruang geografis, psikis maupun kultural di negara-negara yang mengalami kolonialisasi. Nasionalisme menyangkut identitas suatu bangsa yang darinya kita dapat melihat apakah identitas itu merupakan konstruksi dari luar atau sebaliknya.

Wacana nasionalisme Indonesia tidak dapat dilepaskan dari panjangnya sejarah imperial dan kolonial Belanda di Indonesia. Penjajahan di Indonesia yang dilakukan oleh Belanda tidak hanya berhubungan dengan eksploitasi sumber daya manusia dan alam, namun juga konstruksi budaya dan identitas. Manusia Indonesia oleh orang-orang Belanda disebut sebagai pribumi (inlander) dengan segala citra inferioritasnya. Penciptaan stereotipe ini adalah bagian dari proses kategorisasi 'sang lain' (the other) yang dioposisibinerkan dengan diri (the 
self) para penjajah yang berupaya membangun citra superior mereka. Proses reidentifikasi diri menjadi suatu proses pencarian identitas suatu bangsa. Yang kemudian menjadi masalah adalah isu nasionalisme yang kerap dikedepankan di dalam pencarian identitas menjadi sesuatu yang absurd ketika disadari bahwa nasionalisme yang disemai dari batas wilayah kebangsaan adalah konstruksi struktur buah karya bekas penjajah (Young, 2001: 59).

Konstruksi terhadap identitas tersebut mempengaruhi ruang gerak bangsa Indonesia. Bangsa sebagai hasil overwrite dari ruang kolonial merupakan hasil dari penindasan terhadap ruang-ruang lokal yang lebih kecil. Wacana kebangsaan adalah legitimasi penindasan dalam ruang internal yang membutuhkan ruang alternatif dari pembebasan atas penindasan. Hal ini dapat muncul dalam ide-ide tentang nasionalitas atau kebangsaan sebagai bentuk dari resistensi negara terjajah terhadap kolonial.

Menurut Sara Upstone, inti dari postspace adalah sebuah gerakan menuju alternatifalternatif untuk melihat ruang poskolonial dalam istilah nasional. Pengarang novel kolonial kontemporer meletakkan 'nation' dalam konteks sejarah anti-kolonial yang melatarbelakangi munculnya kesadaran nasional dalam rangka pembebasan atau kemerdekaan bangsa. Konsep pembebasan dari kekuatan kolonial paling dapat diamati dalam skala nasional. Oleh karena itu, pembahasan mengenai apa itu nation dan nationalism menjadi penting.

Dalam kaitannya dengan kritik sastra, poskolonial dipahami sebagai suatu kajian tentang bagaimana sastra mengungkapkan jejak perjumpaan kolonial, yaitu konfrontasi antarras, antarbangsa, dan antarbudaya dalam kondisi hubungan kekuasaan tidak setara, yang telah membentuk sebagian yang signifikan dari pengalaman manusia sejak awal zaman imperialisme Eropa (Day dan Foulcher, 2008: 2-3). Jadi, menurut Day dan Foulcher, kritik poskolonial adalah strategi membaca sastra yang mempertimbangkan kolonialisme dan dampaknya dalam teks sastra, posisi, atau suara pengamat berkaitan dengan isu tersebut.
Santosa (2009: 147) dalam artikel 'Perlawanan Bangsa Terjajah atas Harkat dan Martabat Bangsa: Telaah Postkolonial atas Tiga Sajak Indonesia Modern' menyatakan bahwa kesadaran kebangsaan mengenyahkan penjajahan merupakan persoalan nasionalisme suatu bangsa. Nasionalisme di wilayah jajahan merupakan reaksi dari tekanan sosial dan politis yang beraneka macam dari para penjajah. Indonesia telah mengalami penjajahan berulangulang, seperti penjajahan Portugis, Belanda, Inggris, dan Jepang. Jejak penjajahan bangsa Eropa dan bangsa Asia Timur Raya tersebut di Indonesia terekam secara jelas dalam sastra Indonesia modern, misalnya dalam tiga sajak Indonesia modern, yaitu sajak Hang Tuah karya Amir Hamzah yang merekam jejak perlawanan terhadap kolonial bangsa Portugis; sajak Apa Kata Laut Banda karya Mansur Samin yang merekam jejak perlawanan pahlawan Maluku terhadap kolonial bangsa Belanda; dan sajak Sontanglelo karya Mansur Samin yang merekam jejak perlawanan pemuda Batak terhadap penjajahan bangsa Jepang.

Kita juga mengenal Angkatan Pujangga Baru yang memiliki karakter yang kental dengan nasionalisme. Dapat dilihat karya-karya Muh. Yamin, Syahrir, Sanusi Pane, dan Sutan Takdir Alisjahbana yang menawarkan pembebasan diri sebagai bangsa atau manusia yang mandiri. Namun, meskipun karya-karya tersebut diwarnai nasionalisme, bukan berarti kekuatan kolonial sama sekali tidak bisa ditemukan. Terkadang justru melalui nasionalisme tersebut, kekuatan kolonial terbukti masih melekat dalam alam bawah sadar pemikiran bangsa Indonesia. Hal ini tercermin dari karya-karya sastrawan Indonesia, tidak hanya karya-karya pascapenjajahan Belanda, namun juga karya-karya yang dibuat jauh setelah Indonesia merdeka.

Salah satu karya yang memiliki warna nasionalisme adalah cerpen "Mardijker" karya Damhuri Muhammad. Cerpen ini dimuat di harian Suara Merdeka edisi Minggu, 18 Januari 2009. Cerpen ini diwarnai dengan sepenggal sejarah tentang seorang tuan tanah Belanda yang keberadaannya di Indonesia 
menjadi pelopor anti-perbudakan di daerah Depok, yaitu Cornelis Chastelein. Tokoh utama dalam cerpen ini adalah Natan Soedira, seorang gembel yang setiap hari duduk di pelataran depan Latanza Café, tempat anak muda zaman sekarang nongkrong dan bergaul menghabiskan waktu. Gembel itu setiap pukul setengah lima sore meneriaki tamu-tamu café bahwa mereka adalah 'mardijker' seperti dirinya. Setelah ditelusuri oleh Timor, pemuda pelanggan Latanza Café, ternyata gembel itu bernama Natan Soedira. Nama 'Soedira' adalah nama marga dari para budak yang dibebaskan oleh Cornelis Chastelein, tuan tanah yang berkuasa di daerah itu ratusan tahun yang lalu. Chastelein memiliki sebuah landhuis atau villa yang mungkin saja menjadi bangunan Latanza Café sekarang. Dalam surat wasiatnya, Chastelein menyebutkan marga 'Soedira' sebagai satu-satunya pewaris villa itu. Namun, sebelum Timor mengungkapkan temuannya dalam rangka mengusir si gembel, ternyata Natan Soedira tidak pernah lagi muncul. Apa sebenarnya arti kata 'mardijker'? Apa tujuan Natan Soedira meneriaki tamu café dengan sebutan itu?

Dapat dikatakan bahwa Damhuri telah menuliskan cerpen yang mengandung perlawanan terhadap kolonialisme yang tercermin dari perilaku tokoh Natan Soedira. Pertanyaannya, benarkah ini merupakan bentuk nasionalisme yang merupakan kecintaan terhadap bangsa sendiri atau justru menunjukkan kekuatan kolonial yang masih membayangi pemikiran bangsa Indonesia yang telah merdeka. Dalam tulisan ini akan diuraikan bagaimana nasionalisme yang tercermin dalam perilaku tokoh utama cerpen ini melalui perspektif poskolonial.

\section{Pemahaman tentang Nasionalisme}

Berbagai pengertian tentang nation dan nasionalisme telah banyak dikemukakan. Brian Jenkins dan Spyros Sofos (1996: 5) menyatakan bahwa nation adalah suatu konstruksi sosial, sementara 'nasionalisme' adalah suatu proyek politik, sehingga jika kita hendak menganalisisnya tidak bisa hanya mengacu pada bayang-bayang ekonomi sosial dan perubahan budaya, melainkan juga harus melihat pada aspek konjungtor politik serta kepemimpinan politik yang selalu berubah dan tak terprediksikan.

Definisi lainnya mengenai nasionalisme dikemukakan Anthony Smith (2003) yang merumuskannasionalismesebagaisuatugerakan ideologis untuk mencapai dan mempertahankan otonomi, kesatuan, dan identitas bagi suatu bangsa yang aktual atau bangsa yang potensial (Smith, 2003: 11). Pemaknaan lain yang sangat artikulatif dikemukakan oleh Ernest Gellner yang memaknai nasionalisme sebagai sebagai ideologi politik dan kebudayaan modernitas.

Dalam perspektif poskolonial, nasionalisme dikonstruksikan secara berbeda meskipun pada dasarnya sama, yaitu untuk menyatukan kesadaran bersama akan pentingnya memberikan loyalitas berbagai kelompok yang berbeda secara etnik, bahasa, agama, suku, warna kulit, dan lain-lain kepada suatu bangsa yang lebih besar (Tiller, 1997: 32). Pandangan seperti ini juga terjadi di Indonesia yang dalam beberapa orde pemerintahan digunakan untuk menghadapi problem bangsa. Di Indonesia masalah terbesar yang dihadapi adalah penyatuan bangsa atau integrasi nasional yang kompleks dalam satu entitas padu dan tidak terpecah-pecah. Obsesi akan terbentuknya nasionalisme yang kuat dan terintegrasi secara penuh merupakan pencapaian tertinggi yang hendak diraih oleh pemerintah dan elite politik Indonesia dari zaman kolonial hingga sekarang. Namun, kesulitan tercapainya integrasi nasional ini juga tidak lepas dari kuatnya pengaruh yang ditinggalkan oleh rezim kolonial. Nasionalisme yang muncul alih-alih menolak konsep-konsep identitas kebangsaan hasil konstruksi kolonial mengenai Indonesia, melainkan justru tanpa disadari melanggengkan konstruksi tersebut.

Konsep-konsep identitas Indonesia dengan segala budaya ketimurannya serta gagasan mengenai kemajuan, peradaban, dan sebagainya yang dikemukakan oleh kolonialis merupakan alat legitimasi bagi tindakan- 
tindakannya terhadap masyarakat yang dijadikan koloni. Hal ini senada dengan apa yang disebutkan oleh Robert Cribb (1999: 12), sejarawan dari Queensland University, Australia, bahwa dorongan akan kewajiban bangsa Eropa untuk mengajarkan nilai-nilai luhur Eropa-lah yang membuat bangsa Eropa menjajah negaranegara timur yang dianggap sebagai bangsa yang masih primitif dan tak berbudaya.

\begin{abstract}
"...the colonial administration began to hear the siren call of a mission civilisatrice. An important part of the ideology of late European imperialism, this was the idea that Europeans had a duty to impart to those whom they ruled the supposed blessing of western civilization. The resulting expansion of Europeans-language education opened a bole in the colonial edifice through which western ideas could be transmitted to and diffused among large numbers of people in the archipelago. These changes made the first two decades of the twentieth century an intellectually lively time of learning and questioning in the archipelago" (Cribb, 1999: 12).
\end{abstract}

["Pemerintah kolonial mulai mendengar panggilan mission civilisatrice suatu aspek penting dari ideologi imperialisme Eropa waktu itu. Menurut gagasan itu, orang Eropa mempunyai kewajiban mengajarkan kepada penduduk yang mereka kuasai apa yang dianggap sebagai berkat peradaban Eropa. Perluasan pendidikan dalam bahasa Eropa yang mengakibatkan terbukanya celah di bangunan kolonial lewat mana ide Barat dapat disebarkan di antara sejumlah besar penghuni Nusantara. Perkembangan ini menjadikan dua dekade pertama abad kedua puluh di Nusantara suatu masa yang secara intelektual menggairahkan sebagai kesempatan belajar dan bertanya"] (Cribb, 1999: 12).

Seperti yang telah disampaikan di atas, melihat nasionalisme di Indonesia tidak bisa dilakukan dengan melepaskannya dari sejarah kolonialisme Belanda. Hubungan antara keduanya, menurut Faruk (1995: 1) dapat dilihat dalam dua tataran, yaitu tataran universalitas dan tataran kontekstualitas. Dalam tataran universal, nasionalisme Indonesia pertamatama adalah sebuah gerakan emansipasi, keinginan mendapatkan atau membangun (kembali) sebuah dunia yang luas, bebas, yang di dalamnya dan dengannya manusia dapat menghidupkan dan mengembangkan serta merealisasikan dirinya sebagai subjek yang mandiri, bebas, dalam sebuah bentuk yang dapat diraba. Nasionalisme ini dipertentangkan dengan imperialisme atau kolonialisme, gerakan yang didorong oleh kehendak dari satu pusat metropolitan untuk mendominasi, menguasai, menghuni, dan mengatur sebuah wilayah yang jauh (Said, 1993: 8) yang didasarkan pada kebutuhan akan petualangan (Nieuwenhuys, 1982: 53) dan realisasi diri sebagai manusia terpilih yang berhak atas dunia baru yang dijanjikan Tuhan dan sekaligus berhak untuk menjadi juru selamat dunia (Kohn, 1984: 14; Nieuwenhuys, 1982: 8; Abrams, 1971). Dalam tataran kontekstual, nasionalisme Indonesia merupakan kehendak untuk membangun sebuah dunia yang di dalamnya manusia Indonesia (Timur) dapat merealisasikan dirinya secara bebas, lepas dari tekanan dominasi Belanda (Barat). Ini membatasi gagasan pembebasan hanya pada hubungan antarbangsa yang dapat membuatnya bertentangan dengan gagasan pembebasan pada tataran yang lebih rendah, seperti tataran pribadi, kelompok, kelas, dan sebagainya.

Dalam mewujudkan kehendak di atas, orang Indonesia tertarik ke dua arah yang berlawanan: nasionalisme sentripetal, ke masa lalu (Timur), menganggap dunia itu sudah ada sebelumnya dan dapat ditemukan kembali, dan nasionalisme sentrifugal, yang bergerak ke masa depan, menganggap dunia itu sebagai bangunan yang akan atau sedang dalam proses pembentukan (Barat, sintesis antara Timur dan Barat). Nasionalisme sentrifugal cenderung lebih dominan. Namun, bukan berarti bahwa kecenderungan nasionalisme sentripetal lenyap sama sekali. Kecenderungan kembali ke masa lalu merupakan arus bawah yang terus hidup, mereproduksi dirinya dan membayangi nasionalisme sentrifugal tidak hanya melalui teori, praktik, dan sikap tokoh pergerakan nasional, melainkan juga melalui teori, praktik, 
dan sikap kelompok tradisional dan feodal yang masih terus hidup dan berpengaruh luas di kalangan masyarakat (Kartodirjo dalam Faruk, 1995: 3-4). Kebertahanan hidup nasionalisme sentripetal di sekitar nasionalisme sentrifugal juga dimungkinkan oleh sifat idealistis dari dunia yang ingin mereka bangun atau dapatkan kembali serta oleh penolakan mereka kepada masa kini, kenyataan sejarah yang mereka alami berupa struktur sosio-kultural kolonial Belanda (Faruk, 1995: 4).

Nasionalisme dalam karya-karya sastra dapat diamati dari karya sastrawan Pujangga Baru melalui majalah Pujangga Baru yang pertama terbit tahun 1933. Orientasi karyakarya Pujangga Baru tergolong ke dalam nasionalisme yang sentrifugal yang menganggap bahwa dunia ideal yang dibutuhkan orang Indonesia merupakan sebuah dunia baru yang akan atau sedang dalam proses pembentukan. Para sastrawan Pujangga Baru menengok ke 'sejarah zaman baru'-nya sendiri dan ke berbagai pusat kesenian dunia meskipun mengalami hambatan. Namun, arus bawah yang sentripetal juga turut mengisi majalah Pujangga Baru dengan berbagai tulisan yang cenderung memuja kebesaran masa lalu.

Puisi-puisi dalam majalah Pujangga Baru gagal dalam mencerminkan gerakan ke arah pembangunan kebudayaan baru, dan justru mencerminkan suatu kebuntuan kebudayaan. Pujangga Baru bukan membangun sebuah dunia baru yang sudah tertentu dan jelas, melainkan hanya membangun harapan akan dunia baru bagaimanapun samar-samarnya. Dunia baru itu dapat mengambil model dari kebudayaan Barat atau sintesis antara Timur dan Barat, bahkan dapat pula disisipi oleh keinginan kembali ke masa lalu, ke Timur, sebab idealismenya masih samar-samar. Orientasi puisi Pujangga Baru terpecah antara nasionalisme sentrifugal dan sentripetal. Persamaannya, ruang pemenuhan nasionalisme itu selalu berupa sesuatu yang serba harmonis, utuh, sempurna dan indah. Akan tetatpi, semuanya selalu berupa sesuatu yang sudah tenggelam, dan bahkan hilang di masa lalu, tersembunyi di seberang laut atau di atas langit. Ruang itu hanya samar-samar dan berfungsi untuk membangun harapan dan kenangan.

Penulisan drama tradisi Pujangga baru tercatat sejak sebelum 1926. Nasionalisme drama Indonesia benar-benar lahir dari lingkungan organisasi pergerakan nasional, seperti karyakarya Rustam Effendi, Muhammad Yamin, dan Sanusi Pane. Nasionalisme juga terlihat dari latar dan masalah yang diambil, yang memberikan perhatian pada sejarah sendiri, kebangkitan dan berkobarnya semangat generasi muda untuk merebut kembali tanah air dan kemerdekaannya. Akan tetapi, naskah drama itu juga secara terselubung mengekspresikan penyangkalan terhadap semangat dan harapan itu.

Novel Indonesia pertama yang mengungkapkan gagasan nasionalistis adalah Salah Asuban karya Abdoel Moeis tahun 1928. Novel ini juga menawarkan gagasan mengenai dunia baru yang lebih luas, bebas, tidak terbatas sebagai alternatif dari dikotomi Timur-Barat ciptaan kolonial. Hal yang baru dalam novel ini adalah gagasan mengenai 'pulang' yang merupakan sebuah janji yang pasti. Timur merupakan asal dan tujuan yang tidak berubah, sedangkan Barat hanya seperti alat yang dapat diganti, seperti panorama yang ditemui dalam perjalanan. Nasionalisme ini hanya membalikkan hirarki struktur konseptual buatan kolonial tanpa mampu keluar darinya. Dalam Layar Terkembang karya Sutan Takdir Alisjahbana yang dibuat tahun 1937, pertentangan antara Timur dan Barat sudah tidak bermakna lagi serta tidak lagi memperlihatkan kegentaran terhadap sesuatu yang asing. Layar Terkembang menolak sikap yang gentar dan berjarak terhadap dunia melalui tokoh yang hidup penuh semangat dalam dunia. Namun, lagi-lagi novel ini seolah terperangkap dalam ironi konstruktif, mengukuhkan sesuatu yang ingin ditolaknya. Novel ini hanya memberi wadah baru bagi persoalan sama antara Timur dan Barat melalui tokoh-tokoh representasinya. Sementara itu, nasionalisme yang terkandung dalam novel Belenggu karya Armijn Pane (1940) menawarkan dunia nyata yang di dalamnya 
masa lalu bercampur dengan masa depan, angan-angan bercampur dengan cita-cita. Dari perpisahan yang terjadi dalam hubungan pribadi tokoh-tokohnya, mereka lalu masuk ke dalam persatuan yang lebih besar yaitu persatuan dengan masyarakat dan kemanusiaan. Novel ini menghadirkan dunia nyata, dalam artian dunia yang serba terbatas yang di dalamnya terbuka kemungkinan adanya konflik, baik dalam tataran hubungan antarpribadi, kelompok, maupun bangsa.

Dari uraian mengenai nasionalisme dalam karya-karya Pujangga Baru di atas dapat kita lihat bahwa ideologi nasionalisme sastra Indonesia secara terselubung dan tidak disadari sesungguhnya masih terpenjara oleh struktur sosio-kultural ciptaan kolonialisme dan imperialisme Belanda.

\section{Nasionalisme dalam Cerpen "Mardijker"}

Cerpen "Mardijker" bercerita tentang seorang gembel pengemis yang meneriaki tamutamu pengunjung Latanza Café seperti sedang memprotes sesuatu. Apa yang sesungguhnya diprotesnya? Jika dilihat lebih jauh, pengemis itu tidak sekedar melakukan protes kepada tamutamu pengunjung, melainkan kepada suatu kekuatan yang lebih besar yang melatarbelakangi keberadaannya, yaitu kekuatan kolonialisme yang diwakili oleh bangunan kolonial Latanza Café. Cerpen ini juga menunjukkan adanya oposisi antara Barat dan Timur pada masa lalu dan masa sekarang yang ditunjukkan melalui representasinya. Timur diwakili oleh Natan Soedira, seorang gembel yang setiap hari duduk di pelataran Latanza Café, sedangkan Barat diwakili oleh keberadaan Latanza Café yang meliputi pemilik, pelayan, serta tamu-tamunya. Representasi Timur dapat dilihat dari kutipan berikut.

"Satu kakinya diselunjurkan, satu lagi ditekuk guna menyangga tangan yang sedang memegang puntung rokok kretek, tapi belum sempat dinyalakannya. Muka kusutnya masih seperti yang sudahsudah. Bajunya lusuh, penuh tambalan dengan jahitan serampangan. Celana belacunya panjang sebelah, pisaknya bolong, hingga kancutnya menyembul keluar. Tapi, tepat jam setengah lima sore, pada saat pengunjung Latanza Cafe sedang ramai, ia akan tampak berbeda dari gelandangan-gelandangan yang lain" (Muhammad, 2009).

Representasi Bimur dan oposisinya terhadap Timur dapat dilihat dari kutipan berikut.

"Seorang pengusaha dari Jakarta membeli rumah kuno peninggalan zaman VOC itu (kabarnya dengan harga miring), lalu merenovasi sedemikian rupa hingga menjadi Latanza Cafe, tempat nongkrong anak-anak muda kalangan kelas menengah kota ini. Tak perlu cemas dengan teriakan yang meledak-ledak dan setengah mengancam itu. Sebagaimana biasanya, salah seorang pelayan akan lekas membalas teriakan itu dari balik jendela Latanza Cafe" (Muhammad, 2009).

Pada masa lalu pertentangan antara Timur dan Barat terjadi antara pribumi dan Belanda. Timur diwakili oleh kaum-kaum pribumi, sedangkan Barat diwakili oleh Belanda, VOC serta tokoh Cornelis Chastelein dalam cerpen ini. Hal ini juga tertulis dalam kutipan berikut.

"Cornelis Chastelein menginjakkan kaki di tanah Batavia pada 16 Agustus 1674, setelah menempuh pelayaran selama 233 hari dengan kapal t Huis te Cleff. Ia bekerja pada VOC sebagai akuntan.

"Orang-orang yang menggarap lahan itu adalah tawanan perang (berstatus budak) setelah Belanda mengalahkan Malaka, 1941. Cornelis memerdekakan budak-budak itu hingga mereka disebut "Mardijker" atau "orang merdeka" (Muhammad, 2009).

Seperti yang dapat kita lihat dalam cerpen ini, tokoh Cornelis Chastelein tidak digambarkan sebagai Barat yang antagonis. Sebagai catatan sejarah, Cornelis Chastelein adalah seorang keturunan pedagang Belanda 
yang merupakan tuan tanah di daerah Depok pada masa awal kolonisasi VOC di Jawa. Ia merupakan putra dari Anthony Chastelein, seorang Hugenot dari Prancis yang terusir dari tanah kelahirannya dan melarikan diri ke Belanda. Cornelis bekerja sebagai akuntan VOC. Ia juga membeli beberapa bidang tanah di daerah Depok yang dikembangkannya menjadi berbagai perkebunan. Ia mempekerjakan budak untuk mengolah tanahnya dari seluruh penjuru Nusantara. Namun, di kemudian hari Chastelein membebaskan budak-budak tersebut karena tidak sesuai dengan ajaran Kristen Protestan yang dianutnya. Ia memberi 12 marga kepada budak-budak yang dibebaskannya. Budakbudak tersebut dan keturunannya itu kemudian kita kenal sebagai Belanda Depok. Mereka adalah 'mardijker'. Keduabelas marga yang dibebaskan tersebut adalah Bacas, Isakh, Jacob, Jonathans, Joseph, Laurens, Leander, Loen, Samuel, Soedira, Tholense, dan Zadokh. Konon, mereka merupakan sekelompok pribumi Kristen Protestan pertama di Asia. Oleh karena itu, nama keduabelas marga tersebut diabadikan di pintu gereja, sebagaimana dalam kutipan berikut.

"Nama "Soedira" tertera di salah satu pintu dari dua belas pintu gereja itu. Di sebelas pintu yang lain tertulis; Jonathans, Leander, Loens, Bakar, Samuel, Jacob, Laurens, Joseph,Tholense, Iskah dan Zadokh. Nama-nama itu erat hubungannya dengan Cornelis Chastelein, tuan tanah yang pernah hidup di kota ini ratusan tahun silam" (Muhammad, 2009).

Dalam cerpen ini nasionalisme dapat dilihat dari perilaku Natan Soedira yang meneriaki para pengunjung Latanza Café sebagai sebuah protes atas sebuah ketidakadilan yang dirasakannya.

"Lelaki itu akan berdiri dengan dada sedikit membusung, mengacungacungkan jari telunjuk ke arah Latanza Cafe, lalu berteriak, "Rumah itu memang sudah jadi milik kalian. Tapi jangan sombong! Kalian tetap saja Mardijker, sama seperti saya. ...salah seorang pelayan akan lekas membalas teriakan itu dari balik jendela Latanza Cafe. "Kita semua memang orang-orang Mardijker, termasuk kamu." Maka lelaki itu akan diam seketika, dan kembali duduk bersilunjur seperti semula" (Muhammad, 2009).

Natan Soedira menyebut pengunjung Latanza Café sebagai 'mardijker' dan menggolongkannya sama dengan dirinya. Mardijker dalam bahasa Belanda berarti 'orang yang merdeka'. Ini adalah sebutan bagi para budak yang dibebaskan oleh Cornelis Chastelein.

Tokoh Natan Soedira dapat digolongkan memiliki nasionalisme sentripetal, yang kembali ke ingatan masa lalu. Sebagai Timur, ia tidak dapat lepas dari sejarah masa lalunya sebagai keturunan budak yang dibebaskan Chastelein. Ia seolah berusaha mengingatkan para pengunjung Latanza Café bahwa mereka adalah 'orang yang merdeka' dengan menyebut mereka 'mardijker'. Namun, sesungguhnya Natan Soedira terjebak oleh struktur konseptual buatan kolonial tanpa mampu keluar darinya. Kata 'mardijker' sendiri adalah kata yang menggantikan makna sebenarnya yaitu 'budak' atau 'orang yang terjajah'. Jadi teriakan protesnya itu jika dapat ditulis ulang dengan nasionalisme sentripetal, maka akan berbunyi, "Rumah itu memang sudah jadi milik kalian. Tapi jangan sombong! Kalian tetap saja budak, sama seperti saya." dan pelayan café itu akan menjawab "Kita semua memang orangorang budak, termasuk kamu.". Oleh karena itulah Natan selalu langsung terdiam setelah pelayan café membalas dengan menyebut dirinya 'mardijker' juga. Semakin keras ia meneriakkan kata itu, sesungguhnya itu justru mengagungkan apa yang terjadi di masa lalu dan mempertegas bahwa dirinya tetaplah seorang budak.

Selain tidak bisa melepaskan diri dari sebutan 'mardijker' yang melekat pada dirinya, protes Natan Soedira di depan Latanza Café dapat juga dikarenakan perasaan ketidakadilan dan kecemburuan yang dialaminya karena seharusnya ia dapat menikmati kenyamanan Latanza Café seperti pengunjung lainnya. 
Menurut hasil penyelidikan yang dilakukan oleh Timor, seorang mahasiswa pelanggan setia café itu, marga Soedira adalah salah satu nama yang mendapatkan hak waris atas landhuis yang dimiliki Cornelis Chastelein.

"Dalam surat wasiatnya, Chastelein menyebutkan marga "Soedira" sebagai satu-satunya pewaris villa itu, sekaligus dengan koleksi lukisan-lukisan yang sangat berharga itu. Saya teringat pada gembel dengan nama belakang "Soedira" itu” (Muhammad, 2009).

Akan tetapi, Natan Soedira hanyalah keturunan kesekian dari 'mardijker' bermarga Soedira. Kemungkinan landhuis tersebut telah dijual oleh nenek moyangnya kepada seorang pengusaha dengan harga yang murah, sehingga Natan Soedira kini tidak dapat menikmati hidup dalam landhuis tersebut. Natan yang merasa menjadi pewaris landhuis tersebut merasakan kecemburuan sosial yang mendalam, sehingga ia melampiaskannya pada para pengunjung café. Natan Soedira berusaha memperingatkan bahwa yang seharusnya menikmati Latanza Café yang dulunya adalah sebuah landhuis itu adalah dia, bahwa nenek moyangnya lah yang diberi hak waris oleh Cornelis Chastelein atas landhuis tersebut, dan bahwa 'mardijker' lain yang tidak berhak seperti para pengunjung Latanza Café tidak boleh menikmati kenyamanan landhuis itu. Sekali lagi, hal ini semakin mengukuhkan keterikatan Natan dengan dunia masa lalunya, yaitu dunia di mana marga Soedira menjadi marga kesayangan Cornelis Chastelein dan mendapatkan hak-hak istimewa, dunia dimana kekuatan kolonial masih begitu mendominasi seluruh aspek kehidupan bangsa Indonesia.

Tokoh Timor juga menunjukkan nasionalisme sentripetal, meskipun pada awalnya ia terbuka terhadap dunia baru yang bebas dari konstruksi kolonial. Timor merupakan mahasiswa sejarah yang lebih banyak menghabiskan waktunya di café daripada di bangku kuliah. Pada awalnya ia menunjukkan sikap terganggu dengan keberadaan Natan Soedira yang juga mengganggu kenyamanan pengunjung lain di Latanza Café. Ia melakukan penyelidikan terhadap Natan Soedira dengan tujuan awal untuk mengusirnya dari pelataran café agar tidak mengganggu kenyamanannya lagi. Namun, setelah ia mengetahui asal-usul Natan Soedira, Timor justru seolah-olah terbawa nostalgia masa lalu Natan Soedira yang baru ia ketahui. Ini dapat dilihat dari kebiasaannya datang ke Latanza Café setiap malam Selasa Legi sepeninggal Natan Soedira.

"Timor masih saja betah tinggal di sini. Sesekali ia nongkrong di kafe baru itu, utamanya pada malam Selasa Legi, kadang-kadang hingga larut malam", (Muhammad, 2009).

Belum sempat Timor membeberkan teka-teki kata 'mardijker' untuk mengusir Natan Soedira, ternyata ia telah lebih dulu menghilang, tidak lagi muncul dan meneriaki pengunjung café. Konon, ia mati gantung diri di pohon dekat pelataran café, dan hantunya mendatangi café setiap malam Selasa Legi. Mendatangi café pada waktu hantu Natan Soedira mendatangi café memperlihatkan bahwa Timor telah terikat dengan keberadaan Natan Soedira. Ia merasa bisa melakukan sesuatu terhadap Natan Soedira untuk membebaskannya dari masa lalu. Namun kenyataannya malah Timorlah yang tidak dapat lepas dari bayang-bayang masa lalu Natan. Dengan demikian, hal ini semakin memperjelas bahwa perilaku tokoh Timor didasari oleh nasionalisme sentripetal, karena Timor yang semula menolak keberadaan Natan sebagai gembel yang mengganggu di café tempat ia biasa menghabiskan waktu ternyata justru tidak dapat menerima ketiadaan Natan setelah mengetahui bahwa Natan adalah salah seorang ahli waris Cornelis Chastelein.

\section{Kesimpulan}

Cerpen "Mardijker" karya Damhuri Muhammad yang dimuat di harian Suara Merdeka edisi Minggu, 18 Januari 2009 ini mengangkat isu poskolonialisme yang terlihat dari kandungan unsur nasionalisme yang tercermin dari perilaku tokoh Natan Soedira. 
Cerpen ini juga mengandung potongan sejarah mengenai keberadaan kaum Belanda Depok yang merupakan keturunan budak yang dibebaskan oleh tuan tanah Belanda di daerah Depok, Cornelis Chastelein.

Nasionalisme dalam cerpen ini dilihat dalam tataran kontekstual. Nasionalisme yang dimiliki Natan Soedira dapat digolongkan ke dalam nasionalisme sentripetal yang cenderung kembali ke masa lalu dan menganggap dunia ideal itu sudah ada sebelumnya dan dapat ditemukan kembali. Hal ini terbukti dari ketidakmampuan Natan Soedira dalam melepaskan diri dari sebutan yang melekat pada dirinya, sebagai 'Mardijker'. Protes yang dilakukan Natan Soedira kepada pengunjung Latanza Café justru semakin memperkuat keterkaitannya dengan masa lalu. Kecemburuannya atas nasib yang menimpanya pada masa sekarang menariknya kembali pada kenangan masa lalu dimana seharusnya ia dapat menikmati Latanza Café yang dulunya adalah sebuah landhuis yang diwariskan Cornelis Chastelein kepada nenek moyangnya. Selain itu, keberadaan tokoh Timor juga menunjukkan perilaku yang didasari nasionalisme sentripetal karena ia masih terjebak dengan bayang-bayang Natan Soedira yang merupakan keturunan pewaris landhuis Cornelis Chastelein pada masa lalu, meskipun kenyataannya Natan telah tiada.

\section{Daftar Pustaka}

Faruk. 1995. Perlawanan Tak Kunjung Usai. Yogyakarta: Pustaka Pelajar.

Kartodirjo, Sartono. 1993. Pembangunan Bangsa. Yogyakarta: Aditya Media

Keith Foulcher dan Tony Day (Ed.). 2008. Sastra Indonesia Modern: Kritik Postkolonial. Edisi Revisi. Alih Bahasa Koesalah Soebagya Toer dan Monique Soesman. Edisi Pertama 2004. Jakarta: KITLV-Jakarta dan Yayasan Obor Indonesia.

Said, Edward. 1979. Orientalism. New York: Vintage Books.

Upstone, Sara. 2009. Spatial Politics in Postcolonial Novel. England: Ashgate Publising Company.
Young, R.J.C. 2001. Postcolonialism: A Historical Introduction. London: Blackwell.

Sumber cerpen:

http:// suaramerdeka.com/v1/index.php/ $\mathrm{read} /$ entertainmen/2009/01/18/1126/ Mardijker 